\title{
HOMENAGEM AO PROFESSOR OCTAVIO BUENO MAGANO
}

Estêvão Mallet

Octavio Bueno Magano foi uma das pessoas mais extraordinárias que conheci. Como professor, nunca se limitou a apresentar, de modo formal e rotineiro, a disciplina em que se especializou, o Direito do Trabalho. A despeito de suas numerosas ocupações, decorrentes do amplo reconhecimento que obteve, no Brasil e no Exterior, dedicou-se intensamente e com seriedade ao Magistério. Mesmo depois de atingir o mais elevado grau na carreira acadêmica, tornando-se, por concurso público, professor titular da Faculdade de Direito da Universidade de São Paulo, e de receber as mais importantes honrarias jurídicas que alguém jamais poderia ambicionar, continuou a lecionar com o mesmo gosto, interesse e dedicação. Não faltava às aulas c nem as delegava a terceiros. $\mathrm{Vi}$-as sempre com muita seriedade e importância. Ainda as mais simples e rotineiras, sobre temas banais, nunca eram menos do que magistrais conferências, que encantavam pela riqueza da exposição, pela elegância e clareza do estilo, pelo rigor da sistematização, pela erudição dos exemplos. Não me esqueço da ocasião em que, para demonstrar a necessidade de adaptação das normas jurídicas às diferentes condições do meio social, ao invés de apenas enunciar a exigência, como fariam tantos, invocou a carta em que Fradique Mendes censurava o alfaiate Sturmm por não ter sabido cortar, de acordo com a personalidade do cliente, a casaca encomendada (Obas de Eçu de Queiroz, Porto, Lello. 1966, v. III, p. 841). Em outra oportunidade, para sublinhar a importância de rápida aplicação das leis trabalhistas, lembrou que o trabalhador não podia fazer como o pastor Jacob, que, depois de servir sete anos Labão, esperando receber Raqucl, quando frustrada a expectativa, afirmou: "mais servira, se não fora pera tão longo amor lão curla a vida" (Luis de Camões, Sonetos, Lisboa, Clássica Editora, 1969, p. 91). Bem por isso, formouse, entre os seus alunos, uma legião de admiradores.

Os textos que Octavio Bueno Magano deixou, ao lado do impecável estilo, timbram pela profundidade, pela inteligência e pelo valor teórico. Ainda hoje não há como conhecer o Direito do Trabalho no Brasil sem consultar o seu precioso Manual de Direito do Trabalho, de notável riqueza, que, em quatro volumes, percorre a matéria até esgotá-la. Os demais livros que publicou, tais como "Os grupos de empresa no Direito do Trabalho". "Do poder diretivo do empregador" "Convençâo coletiva de trabulho" "Contrato de prazo determinado" "Dicionário jurídico-econômico das relações de

Professor Associado do Departamento de Direito do Trabalho e Seguridade Social da Faculdade de Direito da Universidade de São Paulo. 
trabalho" "Primeirus liçōes de Direilo do Trabalho" e os quatro volumes do "Políica do trabalho" além de outros, são obras de referência, a todo instante lidas e citadas, que fizeram doutrina e influenciaram e influenciam a jurisprudência.

Como advogado, Ocravio Bueno Magano era primus inter pares. Tratava os mais diliceis problemas com a segurança e a tranqüilidade dos mestres. Encontrava altemativas onde todos os demais só viam obstáculos e escolhos. Os arrazoados que redigiu estão repletos não-somente da mais sólida e segura argumentação juridica como, ainda, de lições de graça e de airosidade no escrever. Preocupava-se com o conteúdo e com a forma, pois, como diria Rui Barbosa, que ele muito apreciava, "a inteireza do espirito começa por se caraclerizar no escrúpulo da linguagem" (Réplica, Rio de Janeiro, Ministério da Educação e Saúde, 1953, II, n. 426, p. 307). Quando ocupava a tribuna, brilhava com a eloqüência própria dos verdadeiros oradores, que dominam, por completo, a palavra falada. Todos o ouviam, com interesse, atenção e admiração. Não apenas dizia o que, do ponto de vista técnico, era necessário. Fazia-o de fonna cativante e com encantamento. Mais do que convencia. Maravilhava e arrebatava.

Com a oportunidade que tive ou privilígio, seria melhor dizer de conviver mais amiúde com Octavio Bueno Magano, pudo perceber que as qualidades do advogado e do professor, que de início tanto impressionavam, eram um pequeno detalhe da sua notável e esplêndida personalidade, ornada ainda por muitas outras virtudes. Era autêntico e sincero. Defendia suas crenças e convicçōes com ardor. Como os verdadeiros humanistas, porém, estava sempre com espírito aberto, disposto a ouvir e a refletir, para eventualmente reconsiderar suas conclusões. Não se apegava a idéias preconcebidas e sua inteligência era penetrante e aguçada. De outro lado, à inflexivel correção de caráter aliava a gentileza própria dos grandes, tratando todos com generosidade e distinção. Tinha sempre, nas mais variadas situaçōes ou momentos, um dito amável ou uma palavra elegante para dirigir àqueles com que se relacionava. Sabia incentivar colegas e companheiros, com os elogios adequados, fazendo, com o talento referido por Sêneca, "um terreno diminuto prestar-se...às mais diversas e incriveis aplicações" (Da tranqüilidade da alma, $X, 3$ ). E mesmo nas ocasiōes mais dificeis - e todos nós passamos por elas em alguma quadra da vida - nunca se deixou abater nem pôs de lado a gentileza e a delicadeza.

Em síntese, Octavio Bueno Magano foi realmente uma pessoa extraordinária. Foi como poucos. Será sempre lembrado por todos com saudade, ainda mais intensa e sentida por quem pôde conhecê-lo e privar de sua preciosa e inesquecivel companhia. Dizer mais é até mesmo dificil. As palavras nem sempre expressam bem o que se sente e, na verdade, "nào há palavra que valha um abraço quando ele vem do 
coração", como escreveu Saramago (Cademos de Lanzarote, Lisboa, Caminho, 1998, V. p. 92). Fica, pois, o abraço dos amigos, representado pelos textos que compõem a presente coletânea.

São Paulo, novembro de 2005. 


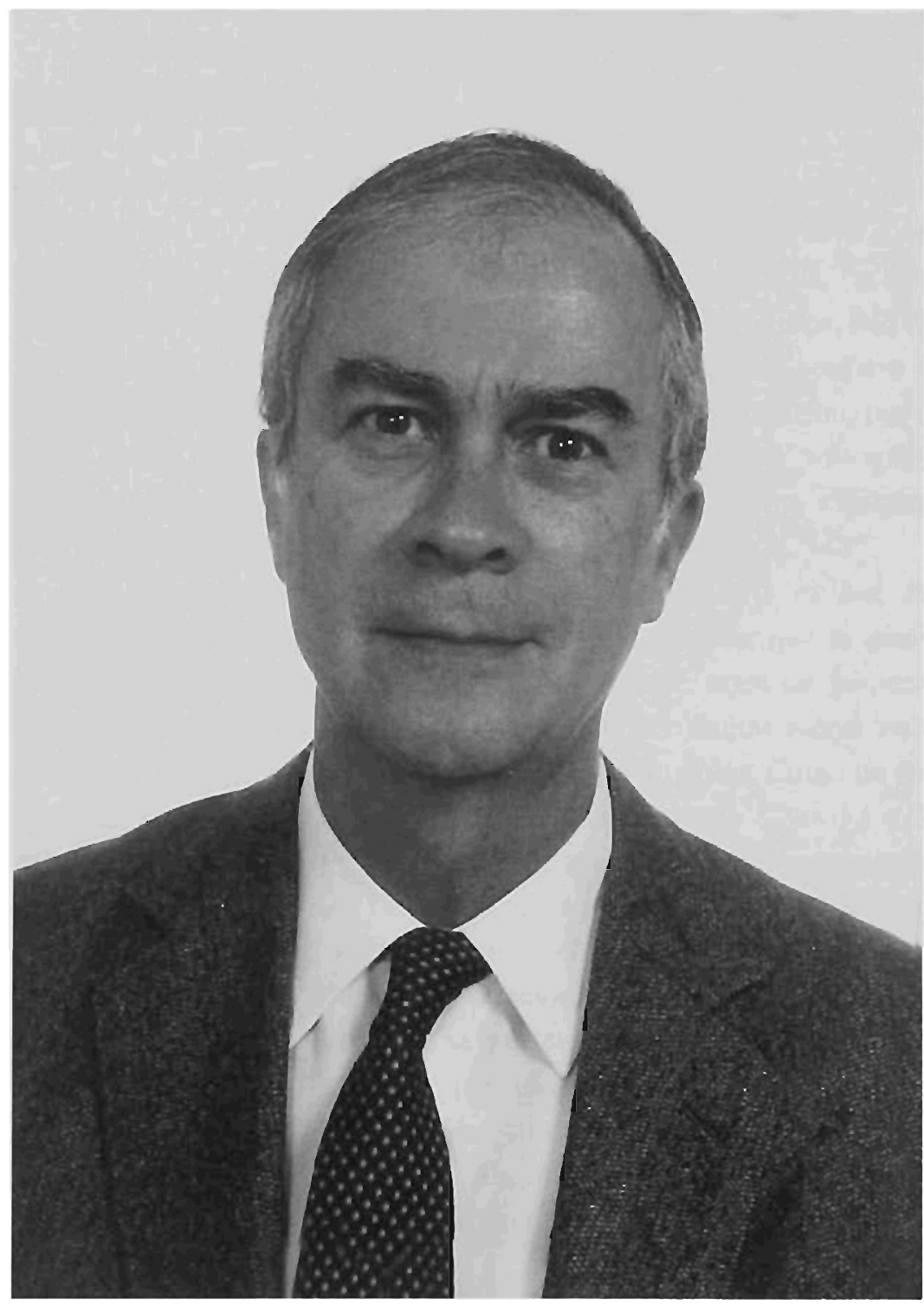

Professor Titular Octávio Bueno Magano 